\title{
Impact of FDI on GDP: A Comparative Study of China and India
}

\author{
Dr. Gaurav Agrawal \\ Assistant Professor, ABV-Indian Institute of Information Technology and Management, India \\ Tel: 91-751-244-9805 E-mail: gaurav@iiitm.ac.in
}

Mohd. Aamir Khan

ABV-Indian Institute of Information Technology and Management, India

Tel: 91-998-141-1972Ｅ-mail: aamiriiitm@gmail.com

$\begin{array}{lcc}\text { Received: May 18, } 2011 \quad \text { Accepted: June 2, } 2011 \quad \text { Published: October 1, } 2011 \\ \text { doi:10.5539/ijbm.v6n10p71 } & \text { URL: http://dx.doi.org/10.5539/ijbm.v6n10p71 }\end{array}$

This research is sponsored by ABV-Indian Institute of Information Technology and Management, India.

\begin{abstract}
Present paper attempts to investigate the effect of FDI on economic growth of China and India. To take care of the issue of structural change in economy, time period of the study is taken to be 1993-2009. First of all we built our modified growth model from basic growth model. The factors included in growth model were GDP, Humal Capital, Labor Force, FDI and Gross Capital Formation, among which GDP was dependent variable while rest four were independent variables. After running OLS (Ordinary Least Square) method of regression we found that $1 \%$ increase in FDI would result in $0.07 \%$ increase in GDP of China and $0.02 \%$ increase in GDP of India. We also found that China's growth is more affected by FDI, than India's growth. The study also provides possible reasons behind China's great show of FDI and the lessons India should learn from China for better utilization of FDI.
\end{abstract}

Keywords: FDI, Growth, Asian economies, Multiple regression, Growth model

\section{Introduction}

Before any discussion can be started on foreign direct investment, it is important to define it for the benefit of readers and for creating common understanding. A simple definition for common understanding can be understood as "Foreign direct investment (FDI) refers to long term participation by country A into country B. It usually involves participation in management, joint-venture, transfer of technology and expertise". Different organizations define FDI differently and the most accepted one is that given by IMF (International Monetary Fund).

IMF defines FDI as "The acquisition of at least ten percent of the ordinary shares or voting power in a public or private enterprise by nonresident investors. Direct investment involves a lasting interest in the management of an enterprise and includes reinvestment of profits".

Today, the world is witnessing the significant impact of globalization which has completely redefined the way in which business used to be done. One of the key results of globalization is that there has been a tremendous growth in global FDI. This dramatic development has taken place simultaneously with a substantial growth in international trade. The term 'Global Village' was coined to indicate that the distance is no longer a constraint and the trade boundaries have become blurred. FDI is an important factor in the globalization process as it intensifies the interaction between states, regions and firms. Growing international flows of portfolio and direct investment, international trade are all parts of this process. Globalization offers an unprecedented opportunity for developing countries to achieve faster economic growth through trade and investment. In the period 1970s, international trade grew more rapidly than FDI, and thus international trade was by far than most other important international economic activities. This situation changed dramatically in the middle of the 1980s, when world FDI started to increase sharply. In this period, the world FDI has increased its importance by transferring technologies and establishing marketing and procuring networks for efficient production and sales 
internationally (Shujiro Urata, 1998). The large increase in the volume of FDI during the past two decades provides a strong incentive for research on this phenomenon.

After the global financial crisis, the status and importance of Asian economies have increased a lot because of their more than expected resilience to financial crisis. Asian economies are expanding rapidly and their growing clout can be felt from the fact that out of top 5 economies of the world (in terms of GDP by PPP) 3 are Asian. Asia, with the exception of Japan, South Korea, Hong Kong and Singapore, is currently undergoing rapid growth and industrialization spearheaded by China and India - the two fastest growing major economies in the world.

India and China have experienced rapid economic growth in recent years. The growth, in part, is attributed to the adoption of liberal trade policies by each country in 1990's, and the consequent surge in the flows of foreign capital to both these countries. China and India, as the two largest developing countries in the world, have been both enjoying fast economic growth since the 1990s. China seems to be performing better. In 1975, China was at par with India in GDP, yet 33\% lower in its GDP per capita (\$146 versus \$220). But over the years China developed more rapidly than India and surpassed India in terms of GDP per capita in 1984. Now, after 26 years there is a huge difference. China is much ahead from India and has left Japan behind to become the $2^{\text {nd }}$ largest economy in the world. China's GDP and GDP per capita are almost 3 times than those of India's.

What's more phenomenal, however, is the difference in their FDI performance. China has been able to attract more FDI than India, both in terms of net inflow and as \% of GDP, from the beginning. Over the past decade, China has established itself as the top recipient of foreign direct investment (FDI) among developing countries. The World Prospectus Survey 2010-2012, released by the United Nations Conference on Trade and Development (UNCTAD), showed that China has once again retained title of the world's most important FDI destination. India, meanwhile, overtook the United States to claim the survey's second spot as the U.S. economy continues to struggle. As has already been discussed China has been receiving substantial FDI compared to India. Although prior to 1980s India received higher FDI than China but because of the liberalization policy adopted by China in 1978, turned the tables in favor of China. Since late eighties and throughout nineties China has been in forefront of the developing world in terms of FDI inflows and hence economic development. So, there is need to investigate the reasons how china has grown more rapidly than India by utilizing FDI.

Given this dichotomy in the economic status of these countries, it would be interesting to know what the effect of FDI on their growth is. The role of foreign direct investment (FDI) in the growth process has for long been a topic of intense debate. Although this debate has provided rich insights into the relationship between FDI and growth, there is very little empirical analysis of the issue, partly because of the lack of a conceptual design and a succinct testable hypothesis. Present paper attempts to investigate the effect of FDI on economic growth of China and India by applying proposed growth model. In second part of the paper we have established relationship between growth and FDI with the support of literature review. In the third part we have explored the previous works done on this and related topics. Fourth part consists of data source and methodology used in this paper. Fifth part shows the findings of the tests applied and their discussion and at last sixth part ends our discussion by concluding the whole essence of the paper.

\section{Previous Research}

\subsection{FDI Promotes Growth: Strong Evidences}

All the countries in the world are continuously striving for rapid economic growth and as a result they are inviting more and more investments by allowing foreign investors to invest in their land. There are several factors that help or hinder the economic growth of a country, and the factors, that are often identified as stimulants (World Investment Report UNCTAD, 1994) for a country's growth are: (1) Large amounts of investment capital, (2) Advanced Technologies, (3) Highly skilled labor, (4) Well-developed transportation and communication infrastructure, (5) Stable and supportive political and social institutions, (6) Low tax rates, and (7) Favorable regulatory environment. Differences in the growth rates of the countries are explained by the differences in the endowments or levels of these factors (Dondeti and Mohanty, 2007).

FDI has long been recognized as a major source of technology and know-how to developing countries. Indeed, it is the ability of FDI to transfer not only production know- how but also managerial skills that distinguishes it from all other forms of investment, including portfolio capital and aid. While foreign portfolio investment may, in some cases, contribute to the capital formation in a developing country, often, the capital flows via this route are limited, and above all, they do not provide the advanced technologies needed to compete in the world markets. FDI can accelerate growth in the ways of generating employment in the host countries, fulfilling saving gap and huge investment demand and sharing knowledge and management skills through backward and forward linkage in the host countries (Frenkel et al., 2004). Moreover, the very presence of foreign owned firms in the 
economy, with their superior endowments of technology, may compel locally owned firms to invest in learning if only to keep abreast of the competition. In turn, increased competition from locally owned firms through their investments in innovation may compel foreign firms to bring in superior quality technology and know-how. FDI generates productivity spillovers for the host economy (Blomstrom and Kokko, 1998). One idea is that multinational enterprises possess superior production technology and management techniques, some of which are captured by local firms when multinationals locate in a particular economy. In sum, imported skills enhance the marginal productivity of the capital stock in the host countries and thereby promote growth (Wang and Blomstrom, 1992). A related source of spillovers is forward and backward linkages between multinationals and host-economy firms (Rodriguez-Clare, 1996), which may result from multinationals providing inputs at lower cost to local downstream buyers or by their increasing demand for inputs produced by local upstream suppliers. Ram and Zhang(2002) also discussed some points which supports the notion that FDI promotes growth: (1) FDI provides the financial resources needed by the host country, (2) FDI acts as a vehicle for the transfer of advanced manufacturing technologies from the DCs(Developed countries) to the LDCs(less Developed countries), (3) FDI increases competition in the host country's markets, (4) FDI helps the host countries improve their foreign exchange reserves (or balance-of-payments position)by increasing exports, (5) FDI brings along with it the management know-how needed to run the facilities, (6) FDI enhances the training and employment opportunities for the people of the host country, (7) FDI reduces the burden of imports on the host countries through import substitution, (8) FDI acts as catalyst for increasing domestic savings and investment. In general, FDI provides ready access to the world markets and acts as a conduit for the host country to participate in the globalization process (Dondeti and Mohanty, 2007).

Though, FDI is seen as a vital factor in inducing growth rate, however, it will only lead to growth if its inflows are properly managed (Bezuidenhout, 2009). The degree up to which FDI can be exploited for economic development depends on conduciveness of economic climate. In the absence of such a climate FDI may be counterproductive; it may thwart rather than promote growth.

\subsection{Literature Review}

The relation between FDI and growth has drawn the attention of scholar quite lately than other research works. Chadee and Schlichting (1997) discuss some aspects of foreign direct investment in the Asia-Pacific Region and conclude that FDI has made a positive contribution to all the economies in that region. Borensztein, etal. (1998) through a study of 69 developing countries confirm that the LDCs(less Developed countries) do benefit from FDI, if they have the capabilities to absorb advanced technologies. The World Investment Report UNCTAD (1999) also describes some econometric models for determining the impact of FDI on growth. After analyzing the data from 11 countries in East Asia and Latin America, using econometric techniques such as unit root and cointegration tests, Zhang (2001) provides evidence that FDI promotes economic growth in countries with a liberalized trade regime, and a workforce with higher job skills and education. According to Ram and Zhang(2002), FDI provides ready access to the world markets and acts as a conduit for the host country to participate in the globalization process. Using co-integration and an error-correction model to examine the link between FDI and economic growth in India, Chakraborty and Basu (2002) suggest that GDP in India is not Granger caused by FDI, and the causality runs more from GDP to FDI. Hsiao and Shen(2003) argue the two way relationship between FDI and growth and support feedback relationship between FDI and GDP. Using a panel data on 84 countries covering the period of 30 years from 1970 to 1999, $\mathrm{Li}$ and $\mathrm{Liu}$ (2004) find that it is an increasingly endogenous relationship between FDI and growth, especially since the mid-1980's. Lee (2005) argues that foreign direct investment along with trade liberalization is the answer for economic development. Hansen and Rand (2006) in their paper titled 'On the Causal Links Between FDI and Growth in Developing Countries' states that FDI promotes economic growth, but the extent to which a country is benefited by FDI depends on its trade policies, labor force skills and absorptive capabilities. Baharumshah and Thanoon (2006) by using dynamic panel models demonstrated the positive contribution of FDI on the growth process of East Asian economies. As contrary, Herzer et al.. (2007) has argued that with 28 developing countries data there exists neither a long-term nor a short-term effect of FDI on growth; in fact, there is not a single country where a positive unidirectional long-term effect from FDI to GDP is found. Chakrabory and Nunnenkamp (2008) analyzed sectoral growth impact of FDI in case of India and found that FDI in the service sector appears to have promoted growth in the manufacturing sector through cross-sector spillovers and thus economic growth. Merican (2009) tested the impact of FDI and Gross Domestic Investment on growth in case of four Asian countries, suggested that the FDI is better than Domestic Investment for growth only in two countries. Whalley and Xin,(2009) examined the contribution of inward FDI to China's recent rapid economic growth using a two stage growth accounting approach and suggested that the sustainability of both China' export and overall economic 
growth may be questionable if inward FDI plateaus in the future. Karimi and Yusop (2009), based on a simple OLS regression, studied the Malaysia's growth-FDI case. According to the authors, there is a range of possible factors that ensure that FDI promotes or hinders economic growth. It would be worthwhile to mention the recent OLS panel study (45 countries over the period 1997 to 2004) of Wijeweera et al. (2010). The main conclusions show that FDI inflows exert a positive impact on economic growth only in the presence of highly skilled labor.

Finally, we can observe that several studies are focused on the case of developing countries and the major part of them stress that FDI, adjusted to other determinants, have a significant positive effect on economic growth. Several of these studies use time-series regression, and panel data analysis to establish the link between FDI and growth. Many of the previous studies used per capita GDP as a substitution for growth but FDI mainly effects the income of labor forces. So using overall GDP of country would show better result. Also not many studies have taken the care of structural discontinuity of GDP. The economies of various countries have gone through the phase of structural discontinuity because of many global events like oil shock, stock market crisis, currency crisis etc. Perron (1989) has pointed out that unless such structural changes are taken into consideration in the analysis, the results obtained may not be valid.

In the present paper we have taken the economies of China and India. Time period is taken from 1993 to 2009 to take care of the issue of structural change in gdp as suggested by V. Redd Dondeti and Bidhu B. Mohanty(2007) that Indian and Chinese economies had undergone structural change in 1992 and 1993 recpectively. The study uses the multiple regression approach to investigate the effect of FDI on growth of these two economies. The study first proposes a growth model taking into account various factors that promotes output(GDP). These factors are mainly identified by litrature review and other research reports and articles.

\section{Research Method}

\subsection{Multiple Regression}

The general purpose of multiple regression is to learn more about the relationship between several independent or predictor variables and a dependent or criterion variable. An example might help. Suppose we were interested in predicting how much an individual enjoys their job. Variables such as salary, extent of academic qualifications, age, sex, number of years in full-time employment and socio-economic status might all contribute towards job satisfaction. If we collected data on all of these variables, perhaps by surveying a few hundred members of the public, we would be able to see how many and which of these variables gave rise to the most accurate prediction of job satisfaction. We might find that job satisfaction is most accurately predicted by type of occupation, salary and years in full-time employment, with the other variables not helping us to predict job satisfaction.

When using multiple regression in psychology, many researchers use the term "independent variables" to identify those variables that they think will influence some other "dependent variable". We prefer to use the term "predictor variables" for those variables that may be useful in predicting the scores on another variable that we call the "criterion variable". Thus, in our example above, type of occupation, salary and years in full-time employment would emerge as significant predictor variables, which allow us to estimate the criterion variable how satisfied someone is likely to be with their job. As we have pointed out before, human behavior is inherently noisy and therefore it is not possible to produce totally accurate predictions, but multiple regression allows us to identify a set of predictor variables which together provide a useful estimate of a participant's likely score on a criterion variable.

In linear multiple regression, the model specification is that the dependent variable, $y_{i}$ is a linear combination of the parameters (but need not be linear in the independent variables). For example, in linear multiple regression for modeling data points there is $\mathrm{p}$ independent variable and $\mathrm{p}$ parameters, $\beta_{0}, \beta_{1} \ldots \ldots . . . \mathrm{p}$ : (Gujarati, 202)

$$
\mathrm{Y}_{\mathrm{i}}=\beta_{1} \mathrm{x}_{\mathrm{i} 1}+\beta_{2} \mathrm{x}_{\mathrm{i} 2}+\ldots \ldots . .+\beta_{\mathrm{p}} \mathrm{x}_{\mathrm{ip}}+\varepsilon_{\mathrm{i}}
$$

where $x_{i j}$ is the $i^{\text {th }}$ observation on the $j^{\text {th }}$ independent variable, and where the first independent variable takes the value 1 for all $i$ (so $\beta_{1}$ is the regression intercept).

\subsection{Model Proposed}

To build our model we started with basic production function. Suppose the factors of production and the production technology determine the level of output in an economy according to:

$$
\mathrm{Y}=\mathrm{f}(\mathrm{K}, \mathrm{L})
$$

where $\mathrm{Y}$ denotes the output level (i.e., GDP), $\mathrm{K}$ denotes the amount of capital (which is measured by Gross Capital Formation (GCF) as percentage of GDP), and L denotes the amount of labor (measured by labor force of 
the country). Assuming constant technology, any increase in the amount of labor and/or capital will increase the level of output in the economy. This production function is expanded according to the new growth theory by following Barro and Sala-i-Martin (1995).

Ogutcu (2002) argues that the Foreign Direct Investment (FDI) is a major catalyst for the development and the integration of developing countries in the global economy. According to Chen (1992), the positive developmental role of FDI in general is well documented. FDI produces a positive effect on economic growth in host countries. One convincing argument for that is that FDI consists of a package of capital, technology management, and market access. FDI tends to be directed at those manufacturing sectors and key infrastructures that enjoy actual and potential comparative advantage. In those sectors with comparative advantage, FDI would create economies of scale and linkage effects and raise productivity. For FDI, repayment is required only if investors make profit and when they make profit, they tend to reinvest their profit rather than remit abroad. Another benefit of FDI is confidence building effect. While the local economic environment determines the overall degree of investment confidence in a country, inflows of FDI could reinforce the confidence, contributing to the creation of a virtuous cycle that affects not only local and foreign investment but also foreign trade and production. Therefore, we have added FDI also in the production function to analysis its impact on economic growth.

Human capital plays an important role in economic growth. Moreover human capital has also been included in the famous Coub-douglas Production Function. Therefore, production function can be expanded by adding human capital (denoted by $\mathrm{H}$ ) as an extra variable. The augmented production function can be written as follows:

$$
\mathrm{Y}=\mathrm{f}(\mathrm{K}, \mathrm{L}, \mathrm{FDI}, \mathrm{H})
$$

Considering the above production function in context of multiple regression, the evaluation of the above function can be done on the basis of following equation:

$$
\mathrm{Y}=\beta_{0}+\beta_{1}(\mathrm{~K})+\beta_{2}(\mathrm{~L})+\beta_{3}(\mathrm{FDI})+\beta_{4}(\mathrm{H})+\varepsilon
$$

Where $\mathrm{Y}=$ Gross Domestic Product

$\mathrm{K}=$ Gross Capital Formation

$\mathrm{L}=$ Labor Force

FDI $=$ Foreign Direct Investment

$\mathrm{H}=$ Human Capital

Further $\beta_{0}$ is the total factor productivity that explains output growth i.e. not accounted by all the four factors and $\varepsilon$ is the error term which is assumed to be white noised. In above equation log values of the variables are used to transform it into a linear one and to facilitate the use of ordinary least square method.

\subsection{Data}

The data set has been collected from the databank of World Bank and has been matched up against the data available on the site of UNCTAD (United Nations Conference on Trade and Development). Above two data sources have been chosen because they are the most reliable sources of data and are used by almost every researcher. On the other hand, the databank from World Bank offers various data arrangement tools, as a result required data can be arranged in desired format and direct exel file can be downloaded. While the weak point is that data sets are not updated quite frequently. The data set consists of GDP(PPP) in current international US Dollars in millions, FDI inflow (as \% of GDP), Gross Capital Formation (as \% of GDP), Labor Force and Human Capital which is proxied by HDI(Human Development Index). Frequency of dataset is annual and covers the time period of 1993-2009.

\section{Empirical Analysis}

Multiple regression is run for China and India separately on the pre specified model:

$$
\mathrm{Y}=\beta_{0}+\beta_{1}(\mathrm{~K})+\beta_{2}(\mathrm{~L})+\beta_{3}(\mathrm{FDI})+\beta_{4}(\mathrm{H})+\varepsilon
$$

Table 1 and Table 2 present the estimated regression models explaining the effect of FDI on GDP of China and India respectively.

Table 1 shows that all variables are significant at 1\% level of significance except FDI which is significant at 10\% level of significance for China. Further the value of $\mathrm{R}^{2}$ and adjusted $\mathrm{R}^{2}$ are quite high $(0.99)$ and Durban Watson stat is 2.01 which is close to 2 (shows that there is no problem of auto correlation). The coefficient of FDI is 0.07 which implies that $1 \%$ increase in FDI would result in $0.07 \%$ increase in GDP of China. 
Table 2 shows that $\mathrm{H}$ (Human Capital) and L (Labor force) are significant at 1\% level of significance; Gross Capital formation $(\mathrm{K})$ is significant at $5 \%$ level of significance while FDI is significant at $10 \%$ level of significance for India. Further the value of $\mathrm{R}^{2}$ and adjusted $\mathrm{R}^{2}$ are quite high (0.99) and Durban Watson stat is 1.96 which is close to 2 (shows that there is no problem of auto correlation). The coefficient of FDI is 0.02 which implies that $1 \%$ increase in FDI would result in $0.02 \%$ increase in GDP of India.

On comparing the FDI performances of China and India, it is evident that China is able to utilize its FDI for growth more efficiently than India. Although significance level of FDI is same for both the countries and coefficients of FDI are not as significant as other variables. India and China, having the largest population in the world, are potentially the world's largest markets and the biggest host countries for FDI from the European Union. Investment from abroad has been a major driving force in the attainment of high growth rates in these countries. It became clear to both the Chinese and Indian governments that their economic takeoff could only be achieved by attracting technology embodied foreign investment. Given their size and their level of development, china and India are apparently direct competitors for FDI. Some of the reasons why China is utilizing its FDI more efficiently than India are:

- Since 1979 China has adopted open door policy and has attracted FDI to modernize its economy while keeping its capitalistic characters. China has adopted a delineated FDI regime in major investment laws and their implementing regulations.

India also adopted the path of liberalization from 1991 onwards but due to lack of political consensus the labor reforms, fiscal reforms has not yet taken place. Also the red tapism, prevailed in the system, unnecessarily causes delay in approval of projects and de- motivates the investors.

- India lags behind China in terms of attracting and utilizing FDI Inflows, in spite of having high-tech industries and adept workforce. The main cause behind this drawback is that India is not skilled enough to adopt the technological advancements at a fast pace.

- Economic activities in India remain less exposed to foreign technologies than other developing countries, despite the increased openness of the Indian economy following the liberalization of trade and foreign investment.

- Like China, India also has large numbers of free trade zones and $100 \%$ export oriented units but location specific and infrastructure bottlenecks hamper their functioning.

- MNCs (Multi National Corporations) bring with them the latest technologies and managerial know how. It depends on host country how much it can exploit these technology transfers. China strongly encourages the transfer and use of technology.

- India's poor performance in terms of competitiveness, quality of infrastructure and skills, productivity of labor, were responsible for less attractive ground for development using Foreign Direct Investment.

\section{Conclusion}

Present paper attempts to investigate the effect of FDI on economic growth of China and India. The study takes care of the issue of structural change in the economy by choosing the appropriate time period with the help of literature review. First of all we built our modified growth model from basic growth model. The factors included in growth model were GDP, Humal Capital, Labor Force, FDI and Gross Capital Formation, among which GDP was dependent variable while rest four were independent variables. After running OLS (Ordinary Least Square) method of regression we found that study confirms FDI promotes economic growth, and further provides an estimate that $1 \%$ increase in FDI would result in $0.07 \%$ increase in GDP of China and $0.02 \%$ increase in GDP of India. We also found that China's growth is more affected by FDI than India's growth and FDI is not as much significant as other variables to predict growth. The study also provides possible reasons behind China's great show of FDI and the lessons India should learn from China for better utilization of FDI. The majority of the foreign investors prefer China over India for investment opportunities as China has a bigger market size than India, offers easy accessibility to export market, government incentives, developed infrastructure, cost-effectiveness, and macro-economic climate. India on the other hand has talented management system, rule of law, transparent system of work, cultural affinity and regulatory environment.

\section{References}

Baharumshah, A., \& Thanoon, M. (2006). Foreign capital flows and economic growth in EastAsian countries. China Economic Review, 17, 70-83. http://dx.doi.org/10.1016/j.chieco.2005.09.001.

Barro, R.J., \& Sala-i-Martin, X. (1995). Economic Growth. New York: McGraw-Hill. 
Bezuidenhout, H. (2009). A regional perspective on aid and FDI in Southern Africa. North West University, Potchefstroom, South Africa, 147.

Blomstrom, M., and Kokko A. (1998). Multinational Corporations and Spillovers. Journal of Economic Surveys, 12, 247-277. http://dx.doi.org/10.1111/1467-6419.00056.

Borensztein, Greorio, De and Lee. (1998). How Does Foreign Direct Investment Affect Growth?. Journal of International Economics, 45, 115-135. http://dx.doi.org/10.1016/S0022-1996(97)00033-0.

Chadee and Schlichting. (1997). Foreign Direct Investment in the Asia-Pacific Region: Overview of Recent Trends and Patterns. Asia Pacific Journal of Marketing and Logistics, 9, 3-15. http://dx.doi.org/10.1108/eb010288.

Chakraborty, C., \& Basu, P. (2002). Foreign direct investment and growth in India: A cointegration approach. Applied Economics, 34, 1061-1073. http://dx.doi.org/10.1080/00036840110074079.

Chakrabory, C., and Nunnenkamp, P. (2008). Economic Reforms, FDI, and Economic Growth in India:A Sector Level Analysis. World Development, 36, 1192-1212. http://dx.doi.org/10.1016/j.worlddev.2007.06.014.

Chen, E. K.Y. (1992). Changing Pattern of Financial Flows in the Asia-Pacific Region and Policy Re-sponses. Asian Development Review, 10, 46-85.

Dondeti and Mohanty. (2007). Impact of Foreign Direct Investment on the Gross Domestic Product, Exports and Imports of Four Asian Countries. Delhi Business Review, 8, 3-23.

Frenkel, M. Funke, K., and Stadtmann, G. (2004). A panel analysis of bilateral FDI flows to emerging economies. Economic System, 28, 281-300. http://dx.doi.org/10.1016/j.ecosys.2004.01.005.

Gujarati, D.N. (2003). Basic Econometrics. (4th Edition ). New York: McGraw-Hill.

Hansen and Rand. (2006). On the Causal Links Between FDI and Growth in Developing Countries. The World Economy, 29, 21-42. http://dx.doi.org/10.1111/j.1467-9701.2006.00756.x.

Herzer, D., Klasen, S., and Nowak-Lehmann, F. D. (2007). In search of FDI-led growth in developing countries: The way forward. Economic Modelling, 25, 793-810. http://dx.doi.org/10.1016/j.econmod.2007.11.005.

Hsiao and Shen. (2003). Foreign Direct Investment and Economic Growth: The Importance of Institutions and Urbanization. Economic Development and Cultural Change, 51, 83-896.

Karimi, M., \& Yusop, Z. (2009). FDI and Economic Growth in Malaysia. MPRA, Paper no. 14999.

Lee. (2005). Foreign Direct Investment and Regional Trade Liberalization: A Viable Answer for Economic Development?. Journal of World Trade, 39, 701-717.

Li and Liu. (2004). Foreign Direct Investment and Economic Growth: An Increasingly Endogenous Relationship. World Development, 33, 393-407.

Merican, Y. (2009). Foreign Direct Investment and Growth in ASEAN-4 Nations. International Journal of Business and Management, 4, 6.

Ogutcu, M. (2002). Foreign Direct Investment and Regional Development: Sharing experiences from Brazil, China, Russia and Turkey. OECD Paper, Paris.

Perron, P. (1989). The Great Crash, the Oil Price Shock, and the Unit Root Hypothesis. Econometrica, 57, 1361-1401. http://dx.doi.org/10.2307/1913712.

Ram and Zhang. (2002). Foreign Direct Investment and Economic Growth: Evidence form Cross-Country Data for the 1990s. Economic Development and Cultural Change, 51, 205-215. http://dx.doi.org/10.1086/345453.

Rodriguez-Clare, A. (1996). Multinationals, Linkages, and Economic Development. American Economic Review, 86, 852-873.

Shujiro Urata. (1998). Japanese foreign direct investment in Asia: Its impact on export expantion and technology acquisition of the host economies. Waseda University and Japan Center for Economic research.

UNCTAD. (1994). World Investment Report. New York:United Nations.

UNCTAD. (1999). World Investment Report. New York:United Nations.

UNCTAD. (2010). World Investment Report. New York:United Nations.

Wang, J., and Blomstrom, M. (1992). Foreign investment and technology transfer: a simple model. European Economic Review, 36, 137-55. http://dx.doi.org/10.1016/0014-2921(92)90021-N 
Whalley, J., and Xin, X. (2009). China's FDI and Non-FDI Economies and the Sustainability of Future High Chinese Growth. China Economic Review, Accepted Manuscript.

Wijeweera, A., Villano, R., \& Dollery, B. (2010). Economic Growth and FDI Inflows:A Stochastic Frontier Analysis. The Journal of Developing Areas, 43, 143-158. http://dx.doi.org/10.1353/jda.0.0059

Zhang and K.H. (2001). Does Foreign Direct Investment Promote Economic Growth? Evidence form East Asia and Latin America. Contemporary Economic Policy, 19 175-185. http://dx.doi.org/10.1111/j.1465-7287.2001.tb00059.x

Table 1. Estimated Regression Model for China Indicating the Factors that Affect GDP

\begin{tabular}{|c|c|c|c|}
\hline Variable & $\boldsymbol{\beta}$-Coefficient & $\boldsymbol{t}$-Statistic & Probability \\
\hline FDI & $0.07^{* * *}$ & 1.93 & 0.07 \\
\hline $\mathrm{K}$ & $0.62^{*}$ & 6.36 & 0.00 \\
\hline $\mathrm{L}$ & $6.6^{*}$ & 9.01 & 0.00 \\
\hline $\mathrm{H}$ & $4.72^{*}$ & 6.64 & 0.00 \\
\hline Constant & $-125.47^{*}$ & -8.53 & 0.00 \\
\hline $\mathrm{R}^{2}=0.99$ & \multicolumn{2}{|c|}{ Adjusted $\mathrm{R}^{2}=0.99 \quad$ Durbin-Watson stat $=2.01$} \\
\hline
\end{tabular}

$*, * *, * * *$ Denotes significance at a $1 \%, 5 \%, 10 \%$ level.

Table 2. Estimated Regression Model for India Indicating the Factors that Affect GDP

\begin{tabular}{|c|c|c|c|}
\hline Variable & $\boldsymbol{\beta}$-Coefficient & $\boldsymbol{t}$-Statistic & Probability \\
\hline $\mathrm{FDI}$ & $0.02^{* * *}$ & 1.76 & 0.10 \\
\hline $\mathrm{K}$ & $0.17^{* *}$ & 2.46 & 0.03 \\
\hline $\mathrm{L}$ & $1.97^{*}$ & 3.48 & 0.00 \\
\hline $\mathrm{H}$ & $6.17^{*}$ & 3.64 & 0.00 \\
\hline Constant & $-27.91^{* *}$ & -2.64 & 0.02 \\
\hline $\mathrm{R}^{2}=0.99$ & Adjusted $\mathrm{R}^{2}=0.99$ & Durbin-Watson $\mathrm{stat}=1.96$ \\
\hline
\end{tabular}

$*, * *, * * *$ Denotes significance at a $1 \%, 5 \%, 10 \%$ level.

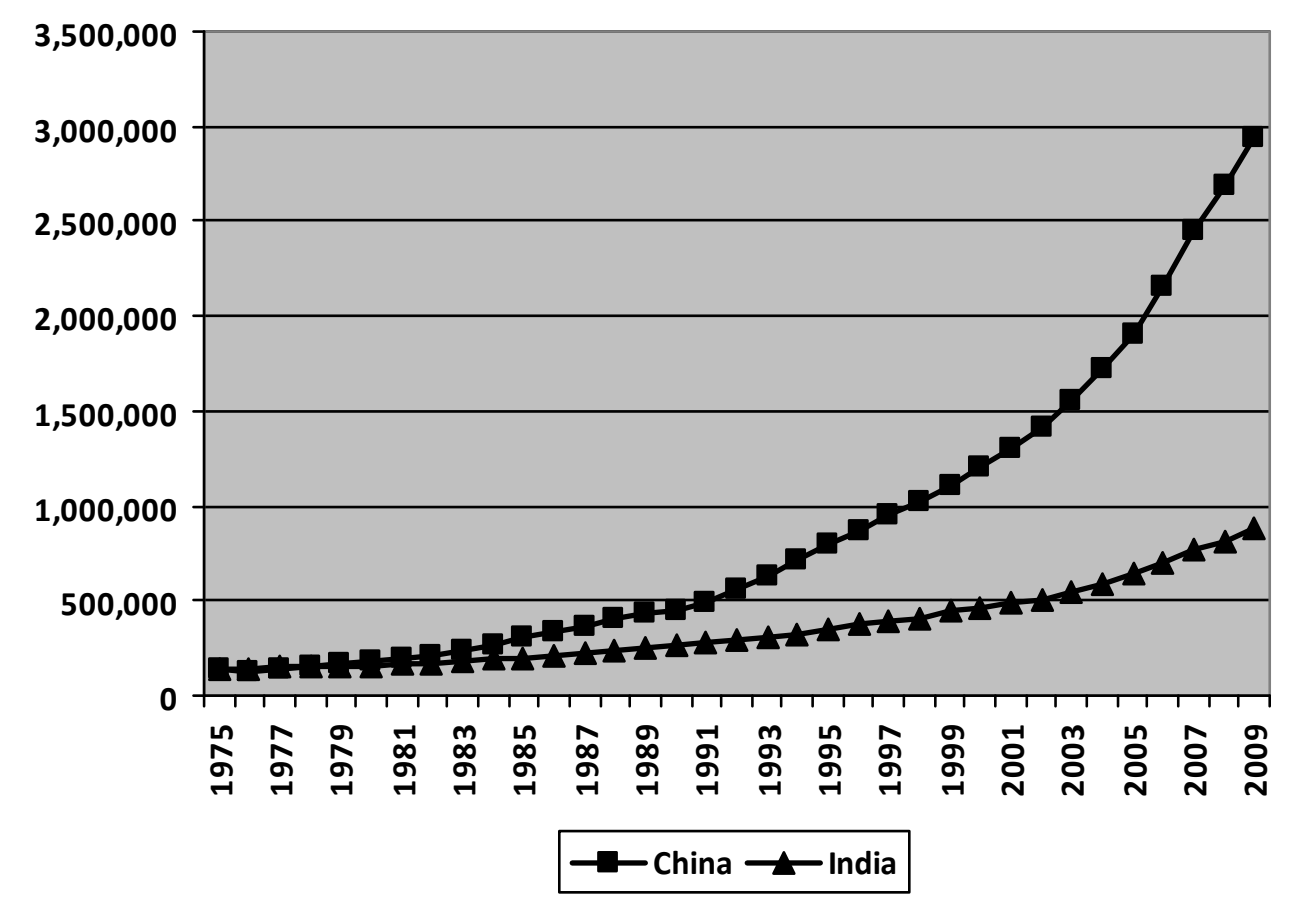

Figure 1. Comparative GDP Growth of China and India (In Current Million US\$) 


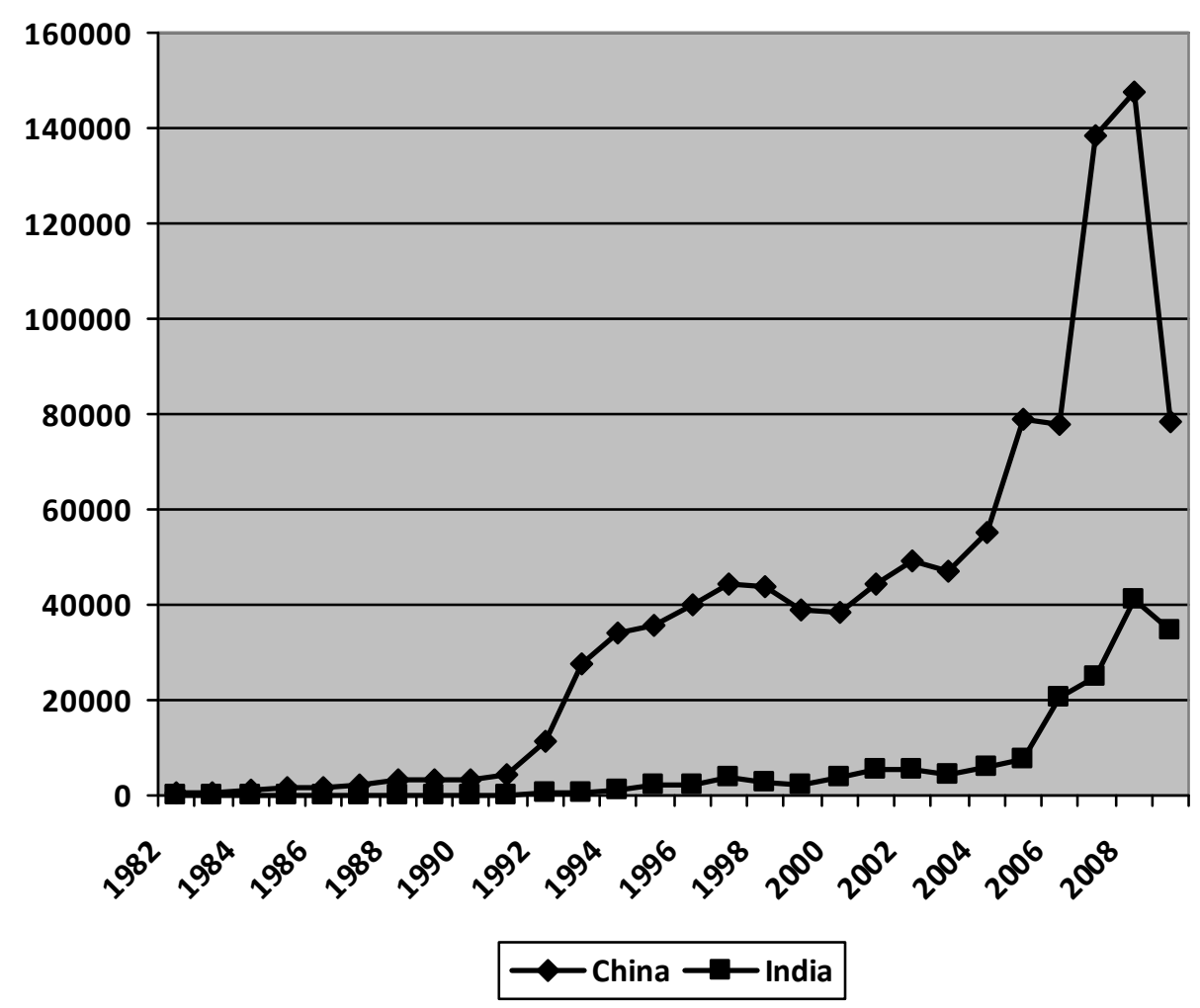

Figure 2. Comparative FDI Inflow in China and India (In Current US\$) 